\title{
The mythopoetical model and logic of the concrete in Quechua culture: Cultural and transcultural translation problems
}

\author{
lleana Almeida \\ Department of Communication, Universidad Central del Ecuador \\ Calle Gatto Sobral O E 9-16 Y Ritter \\ Sector Alto de Lagasca \\ Quito, Ecuador \\ e-mail: ilalo@andinanet.net
}

\section{Julieta Haidar}

Social Anthropology Department, Escuela Nacional de Antropología e Historia Antiguo Camino a la Sierra 15, Casa 1

San Andrés Totoltepec - Delegación Tlalpan

Código postal 14.400 México, D. F., México

e-mail: jurucuyu@gmail.com

\begin{abstract}
This article deals mainly with problems of cultural/transcultural translation between the Quechua and Spanish cultures, analysing these on the basis of some ideas by Juri Lotman and Peeter Torop. The process of translation implies considering the Quechua semiosphere's internal borders as well as the external borders related to the cultures that existed at the time of Tahuantin Suyo, and all changes that have come from the Spanish conquest of Latin America. In the case of the Quechua culture, the problems are numerous and conflicting in several dimensions. First of all, Quechua is an agglutinating language that creates problems for translation into a flexional language such as Spanish. Secondly, and more importantly, there exists a mythopoetical model of the world that has been built in this culture, which does not use concepts of rational logic, but poetic images integrated into mythical thinking: it represents a different cognitive pattern. Thirdly, the presence of the logic of the concrete in Quechua culture, articulated with the mythopoetical model, makes translation from Western abstract formal logic difficult. Reflections on these issues provide new analytical possibilities.
\end{abstract}


"The value of archaic world, of myth and folklore, is not opposed to later art values. It is rather comparable in a complex way with the highest achievements of world culture." Juri Lotman and Zara Mints (1996)

\section{Introduction}

The main objective of this article is to analyse the mythopoetical model and the 'logic of the concrete' present in the Quechua culture that manifest unique and complex performances. These two organically articulated features produce a series of problems of cultural translation between the Quechua and Hispanic worlds in Ecuador. In other words, the processes of cultural/transcultural translation (Lotman, Uspenski 2000b; Torop 2002, 2003, 2010) between the Quechua and Hispanic semiospheres are complex, full of tension, conflicting and lead to theoretical, methodological and analytical challenges which we will be considering in the course of this article.

We start by considering the epistemological perspective of complexity and transdisciplinarity (Morin 1997, 2002; Nicolescu 2009) and relate these to the approach of the Tartu School, as well as to the Quechua cultural episteme. Second, we explain some features of the Quechua world that deserve to be better known. Third, we consider the mythopoetical models of this ancient culture that can be detected also in other ancient cultures. Fourth, we apply Claude Lévi-Strauss's (1964) notion of the 'logic of the concrete', also developed by A. Spirkin (1965), that may be a feature of most non-writing cultures as opposed to the abstract logic of Western languages.

Epistemologies of complexity proposed by Edgar Morin $(1997,2002)$ and of transdisciplinarity proposed by Basarab Nicolescu (2009) are two foremost cornerstones in the study of the Quechua culture and thus make place for it on the same trajectory of importance as other ancient cultures and other hegemonic cultural developments in the current processes of worldwide globalization.

To begin, it is important to differentiate, in cognitive terms, the epistemology from the epistemic, seeing the former as accepted by the academy, while the latter is seen as excluded. However, from the perspective of complexity and transdisciplinarity it is mandatory and necessary to integrate with the same validity all knowledge generated in ancestral and ancient cultures like those of the Chinese, Egyptian, Quechua, Maya, and Aztec, among others 
(Haidar 2004). This allows discussing on an equal footing the hegemony of scholarly thought in the Western culture and the hegemony of other types of thought like the mythical, mystical, magical or religious thought which are developed in the East. In other words, Michel Foucault (1972) and Julieta Haidar (2004) propose that both the epistemological and the epistemic ${ }^{1}$ should be regarded as having the same cognitive value and, keeping in mind the aspects of complexity and transdisciplinarity, should be represented as maintaining a spiral relationship between these two axes. The cognitive processes in ancient cultures, such as the Quechua, relate to the epistemic realm which explains the workings or performances of the mythopoetical model.

In this sense, Morin (2002: 167-183) insists that one type of knowledge that acquired by science - is not enough to access all cognitive complexity, adding that in myth we can see a particular, also complex type of knowledge. As an example of the relationship between scientific and mythical knowledge, we can use the law of modern physics according to which galactic movements have a spiral pattern. These cosmic spirals (the macrolevel) can be argued to resemble the sacred snail with a spiral shell (the microlevel) that is known in the Quechua and other cultures in Mesoamerica. The snail in the Quechua culture (Aguilar Páez 1970) was a polysemic symbol, and so the dancers or sacred subjects carried it over their heads in order to remain united to cosmos.

In the works of Morin (1997: 77-84) and Lotman (1996a: 22-23; 1996b: 43-51) there is a remarkable similarity regarding the continuum between the natural sciences, social sciences, quantitative sciences and arts, which is a cutting-edge approach being developed for following the purpose of rescuing the cognitive continuum which the Western culture has lost. It is most significant that in the mythopoetical model of Quechua we can find a way of thinking that establishes a continuum between nature and culture (also seen in other ancient cultures of Africa, Asia and America), between science and art, between science and religion, thus proposing holistic cosmo-conceptions. ${ }^{2}$

From the perspective of transdisciplinarity as studied by Nicolescu (2009), we address the concept of pacha, as a potential crossing of knowledge: pacha as time, space, order and clothes. This is evident in the names of gods and deified

1 A note on episteme: this category refers to kinds of knowledge that are not related to Western cognition. We argue for a cognitive continuum between the epistemological and the epistemic perspectives.

2 Cosmo-conception is a category to explain the concepts that different cultures have of the cosmos, of the universe, of the whole world. 
kings: Pachakutek, the one who refounds the world, Pachakamak, the one who orders the universe, Pachayachachik, the one who reveals the world. In the mythopoetical model, the spider is Pacha, because it weaves the cosmos from itself, and Pachamama is the feminine creative principle of nature (Torres 1982; Almeida, Haidar forthcoming).

In short, we cannot stick to the idea of static, structural or inherent systems. Thus it becomes necessary to analyse complex, dynamic, recursive and hologrammatic systems, and this requires the construction of transdisciplinary models in order to display all the theoretical and methodological axes involved in an analysis from this perspective. Consequently, the Quechua semiosphere is understood proceeding from these parameters as a non-structural, complex, dynamic, recursive and heterogeneous system, composed by texts and languages with features proposed by Lotman (1996a), Torop (2010), and several other authors.

\section{The Quechua culture: main features}

The Quechua culture ${ }^{3}$ (Quichua in Ecuador) has been studied since the Conquest, so the first Indian and Spanish writers strove to testify and explain the original and heterogeneous set of cultural features which the Quechua people had acquired through long historical processes. In recent decades, such studies have become more complex due to the use of new theories and methods, and also because contemporary research guidelines take into account the characteristics that persist today, as well as how these have become adapted to historical changes.

The Quechua language and culture were widespread even before the consolidation (approximately in the 15th century) of the Inca-Quechua empire Tahuantin Suyo, ${ }^{4}$ bringing about an organic and rapid synthesis, as well as cultural and linguistic homogenization that allowed the development of an original model of the world. The formal characteristics of this model, which achieved greater cohesion in the 16th century, were structured as a set of languages and texts, in which the linguistic, religious, mythical, technical, ethical, political components, as well as all kinds of art, were interconnected.

3 Quechua and Quichua (Kichwa) are different dialects of the same language.

4 "Tahuantin Suyo" refers to the four directions of the world and of the universe, the cardinal points, and the limits of the world (horizontal axis). 
Tahuantin Suyo was a theocratic monarchy. Its main ethnic core consisted of the Quechua people, but there were also people from various other cultures that constituted Tahuantin Suyo. The Quechua language prevailed, as did the solar religion. By the time the Spanish arrived, the Inca state had a stable social system disseminated throughout a vast territory encompassing Peru and much of today's Colombia, Ecuador, Bolivia, Argentina and Chile, while many of these territories were inhabited by Quechuanized populations.

The Quechua culture, which defines the history of Tahuantin Suyo, must be understood in the context of interaction with other cultures, especially those that made great achievements in the material and spiritual spheres, such as the Aymara and the Chimú. To use the terms of Lotman and Torop, there were different semiospheres between which continuous and complex cultural and transcultural translation processes took place. These processes produced drastic changes in the Quechua semiosphere. Throughout its history the Quechua culture received powerful impulses from peoples who were at a stage of development close to the one reached by Tahuantin Suyo; some of these were the Chavin, the Tiahuanaco and the Wari (Doig 1973).

The Quechua cultural life has been conditioned by the peculiarities of a social form which exists also at the present time: local village communities, which retain some features of the old ayllus, where residing groups kept a lineage kind of kinship, land ownership was communal, and the land was periodically redistributed among households (Godelier 1974). Ayllus communities retain and recreate many characteristics of the ancestral culture through the memory function of culture, transmitted from generation to generation.

In the recent decades, however, there has been a constant and growing migration of the Quechua people from the countryside to the cities. Migrants occupy marginal areas of the cities and have conflictive contact with "mestizo" (mixed race) culture. These conflictive semiotic border issues generate continuous processes of cultural/transcultural translations.

Already in the time of Tahuantin Suyo, the Quechua culture had very important and advanced features, such as the notions of the cosmos and spacetime, predecessors of "historical cycles", of family relations, and the role of the Inca as the child of the higher deity (Valcárcel 1964, Vol. II: 471). In all orders of social life, mythic-religious symbols were developed and rites were refined. 
The quipus ${ }^{5}$ (textile art that shows a type of writing and mathematical systems) and architecture (that contained mythical meanings dictated by the official spheres) reached a high degree of perfection and cities were organized containing administrative-religious centres (Valcárcel 1964, Vol. II: 556). Power gave meaning to the artistic and proto-scientific principles, on the basis of which the stars were named, cranial trepanations were made to high warlords, the remains of the rulers were mummified, the quipus were woven, bridges and an extensive network of roads - the Kapak Nan (the Inca Trail) were built (Valcárcel 1964, Vol. I: 683).

In an analysis of changes in the Quechua culture it is necessary to take into account the cultural dialectic movement between the centre and the periphery (Lotman, Uspenski 2000b) which occurs when the peripheral culture penetrates the official culture that aims to extol royal power. Movements in the Quechua semiosphere occur dialectically, between the elite culture and the culture of the community ayllu, and it can be seen that the latter has a great impact on the former in several aspects, although undergoing some transformations: in the development of language to the point of acquiring official status; in the change of a popular cult of Pachamama to that of the cultural god Wira Kocha (a powerful god of the official Inca religion that could not be replaced completely even by the religion of Inti (the Sun), the supreme deity that symbolized the consolidation of the State); in certain Quechua foods which acquired a symbolic status at Incan rituals, e.g. maize that was regarded as a food of sacred offerings; in monumental dimensions reached by the palaces and temples based on the model of the peasants' canch $a^{6}$; in the refined ceramics of the nobility which differed from commonly used pottery; in Incan textiles that were produced with a great degree of perfection to honour the nobility and divinity (tucapu) and incorporated sacred symbols representing the cosmos; in the solemn music accompanying royal rituals - dedicated to the official deities - that mixed music and crying (Valcárcel 1964, Vol. III: 164); in the emergence of priests that came to replace the shamans; in the emergence of historical myths about Incan rulers instead of popular myths about natural phenomena; in the symbolic crop, made by Incas in the chakras (farmland), that was dedicated to the emperor but reminded of the agricultural rites of the community; in the establishment of the royal panakas (urban communities that

5 Knotted cords for counting and narrating with the help of number, colour and texture codes which still remain in the memory of culture.

6 Walled precincts, built in a rectangular shape to represent cosmos. 
assembled the Incan nobility of the Cusco, from which Tahuantin Suyo's sovereignty grew out) that, although being inspired by the ayllus or primitive community, were dedicated exclusively to the rinri sapa ("nobility of blood"); in communal obligations such as the minga (collective work) and the ayni (which was more of an exchange of services according to a social agreement) (Nuñez 1978: 49).

The impact of the ayllu culture on the elite culture is very significant in terms of explaining the complexity of cultural change. The ayllu organization was altered by the Incan power; agricultural products were no longer distributed to all community members, because a large part of the crops were destined for the Incas and for temples (Choy 1978). High culture and the most refined arts fulfilled major social and political functions. It is not difficult to distinguish the Incan rulers' and nobility's ideas of greatness from the spontaneity and simplicity of ayllus communities which were not free from the influence of high culture. Religion and language were ordered by official norms, which make explicit the internal borders of these semiospheres, among which cultural translation processes take place.

The Spanish invasion superimposed their own culture on the Quechua, but the indigenous people have not become detached from their ancient cultural heritage and have often resorted to disguised and alien ways of preventing traditions from disappearing. In general, the manifestations of the culture of the ayllu community are the ones that have persisted more tenaciously, a phenomenon that is linked with the survival of rural communities. In Ecuador, in the community of Agato (Imbabura province), people still dance the solemn dance of Inca with two pallas (noble women of Cusco); the communities of Alangasí (parish of Quito) celebrate the Fiesta de la Palla that is centred around a figure dressed and decorated in the manner of Cusco; in the city of Pujilí, each year the world-men (disguised dancers) perform a highly sacred ritual of the representation of the cosmos with the levels of heaven, earth, and underworld. Heaven is represented by a golden plume decorated with diamonds that stand for the Sun, the stars and the Earth, all together in a crossshape ornament with four directions; the underworld is represented by hanging ribbons. The dance takes place on the summer solstice day. Despite the persistence of the memory of the ayllu community culture, there remains a certain nostalgia for the greatness of the ancient culture (see Almeida, Haidar forthcoming). 
As in other ancient civilizations - Sumer, Egypt, Greece, the Crete-Mycenaean culture, the Mesoamerican cultures of the Mayas and Aztecs (Toporov 2002f: 331) - also among the Incas-Quechua a mythopoetical model of the universe was formed, and this model summarizes and classifies several representation fields of cosmos, nature and society. This Quechua model unifies thought and artistic creation, and it expands to the entire cultural production. Quechua culture, the historical and the present one, reveals a splendid and unique historical experience. The task of preserving and extolling it will not only help to reaffirm the pride of the people, but also to enrich world culture with the unusual typological peculiarities of the Quechua.

\section{The mythopoetical model of the Quechua culture}

To address the mythopoetical model of the Quechua semiosphere, we argue that models of the world in general encompass the systematic representation of a diversity of ideas which summarize the essence of natural, cultural, social, and historical phenomena (Toporov 2002f: 330). In many cultures, these models include the tree as a universal symbol, such as the seiba tree in the Mayan culture, which has several dimensions that link the world below, the visible world of the earth and the world above; also in the Quechua culture the quishuar tree has been considered divine and it still preserves traces of this meaning (Almeida, Haidar forthcoming).

From this perspective, a mythopoetical model of the world is a specific form of intellection of reality, which involves a synthesis of the symbiosis between humans and nature. Through myth and rite, the whole world becomes visible, perceivable and intelligible (Toporov 2002f: 331). We believe that the analysis of any model of the world must engage different theoretical and methodological angles, assuming the need for a transdisciplinary approach which may involve philosophy, art theory, psychology, sociology and other fields of cognition. However, for the analysis of the mythopoetical model of the world, it seems that semiotics, and semiotics of culture in particular, provide the most comprehensive and richest heuristic tools. To address the mythopoetical model, it is worth pausing to consider the polysemous and polemic discussion concerning mythological characteristics and peculiarities. Studies of the appearance of myths are countless and virtually all anthropologists have addressed the subject both in the West and in the East. For Claude Lévi-Strauss (2002), myth is a special kind of thought and knowledge that is developed for 
understanding the world. The essence of the mythical logic, according to Yakov Golosovker (Zenkin 1988: 300), lies in the possibility that at any time the elimination of the properties and qualities of the sensorial-perceived material world can happen, without invalidating this world's materiality.

As suggested by Lotman (1998a: 83-84), the first myths we know were not narrated, they became visible in the rock paintings and lithic carvings of the Paleolithic. In addition, according to Lotman (1998b: 29) in primordial myths the arrangement of elements is not linear, so "being" is represented in an arrangement of concentric circles, between which a relation of homeomorphism exists. Let us check Lotman's suggestions with regard to a lithic sculpture called Estela Raimondi at a Peruvian archaeological site Chavin de Huantar. The sculpture represents a deified being in a headdress that conventionally "descends" along his back with the central image reproduced several times as waves that spread to the periphery (Doig 1973).

The earlier forms of mythopoeisis are complex to understand, because they involve continuous processes of cultural/transcultural translation, which is always a challenge to face, as we have mentioned before. In cognitive terms, a very important question arises about the motivations that lead human beings to try to know through imagination, creating mythological images to perceive reality. According to Golosovker, a specialist in mythological subjects, there exists an instinct of culture or of imaginative absolute in humans (Zenkin 1988). Mythology is the most emblematic example of the intellection of the world based on imagination, through the image-sense (images of conventionalized content) which is not separated from cognitive processes. The imagesense has the function of appointment and substitution of reality, not only by its tangible character, but by its semantic capacity to condense meanings.

The Quechua mythopoetical model of the world contains elements of the universality of mythological thought that can be found in diverse and remote cultures with which extraordinary similarities can be found. According to Lotman (1996c: 95), one feature of the mythologically oriented culture is the rise of a connecting link between language and texts: the code-text, which we will try to illustrate or exemplify through some myths and symbols, such as, e.g., the llama coming down from heaven; the world-men; certain buildings like Kenko near Cusco, which are simultaneously a text and a code (we will address this in more detail later on). As Lotman points out in several articles, the importance of myth lies in that it embodies the memory of culture, which is generated and regenerated in the collective dimension, which explains the 
importance of mythical stories in the conservation of culture, for they contain distinctive mnemotechnical processes of the oral tradition, not of the written word. In other words, collective memory explains how in the context of a new era, the text, with all of its interpretations, preserves the quality of being identical to itself (Lotman 1996e: 157-158).

In the ancient Quechua mythopoetical model of the world, space is one of the most transcendental elements, linked to time. It is a concept related to the operations of spatial segmentation and integration, signalling the key spaces. In addition, what needs to be highlighted is that mythological consciousness, the chronotope (Torop 2002) expresses an indissoluble unity of space and time that can be illustrated with the lexeme 'spacetime' which we will discuss below in the section dedicated to the logic of the concrete.

According to Vladimir Toporov (2002e: 178), a specialist from the TartuMoscow School, for mythic consciousness "the space is animated, spiritualized and qualitatively heterogeneous. It is not abstract or empty and does not precede the things that fill it; on the contrary, it is constituted by them. It is always full and always by things; apart from things that do not exist."

In Lotman's (1996d: 83-84) view, the construction of the order of the world is conceived on the basis of a spatial structure that organizes all its other levels. In case of the archaic world model of the Quechua culture, it is essential to characterize the mythopoetical model spatially, because spatial conceptions are the ones that shape it and cosmologize the most important parts of the universe (Almeida 2009).

In ancient mythological space, the world is represented by two kinds of schemes: vertical and horizontal. The Quechua vertical scheme has the meaning of number three as its reference, and it is directed syntagmatically, as a top-down succession, on a single temporal plane. The Quechua vertical scheme is composed of the upper world or Hanan Pacha, "Sky"; the world "here" or Kay Pacha, "Earth"; and the Uku Pacha, the underworld, in which the logic of the concrete can be seen.

The embroidered suit of a Pujilí dancer (Ecuador, Cotopaxi province) represents the three levels of the Quechua cosmos: the Hanan Pacha or upper world, where stars and birds are located; the Kay Pacha or the earth with its four paths or ways, and the Uku Pacha or underworld, where chaos and its diffuse forms reign. In the context of an approach involving complexity and transdisciplinarity, the three levels must be thought of as a continuum. 


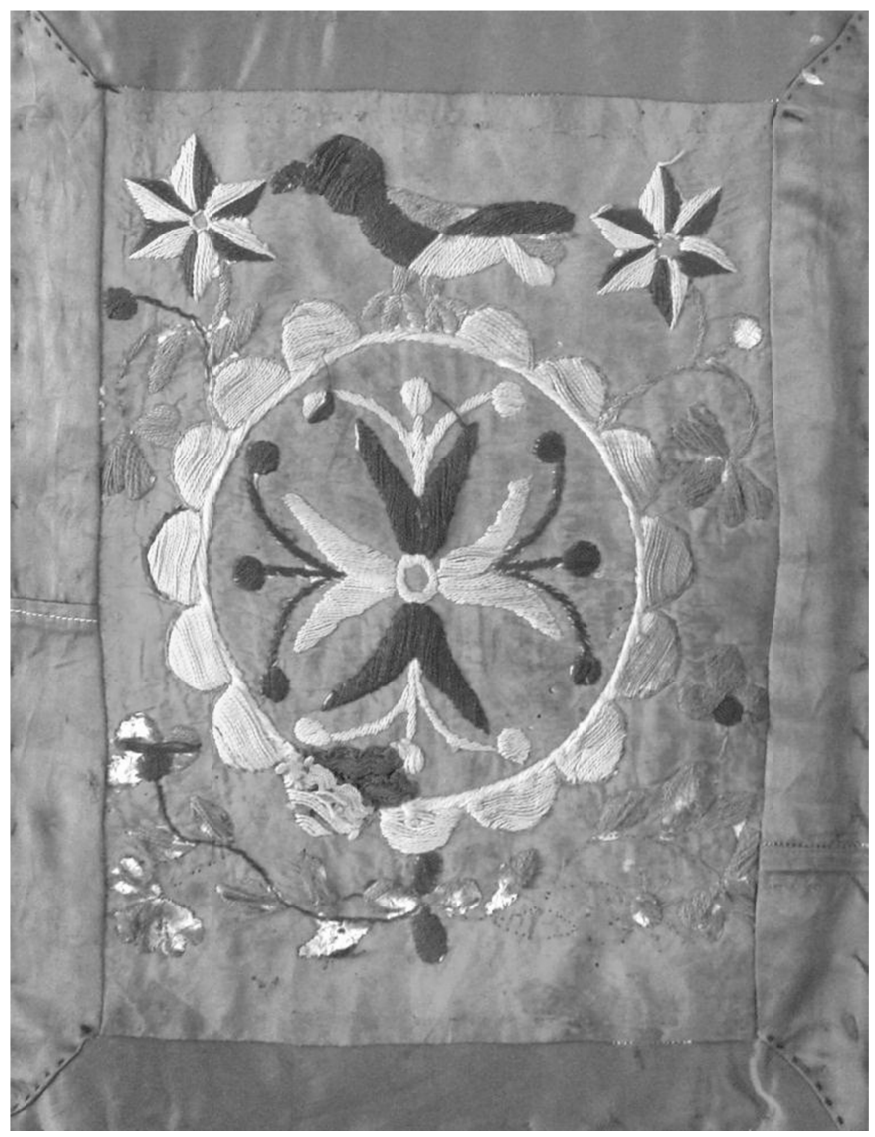

Figure 1. Pacha.

The three levels are present in this image; the reading should be carried out starting from above along the vertical scheme or axis (this spatial scheme constitutes a cultural universal):

Hanan Pacha: Upper world (birds and stars);

Kay Pacha: Earthly world (in which the square and the circle overlap, showing the four ways or paths of the universe);

Uku Pacha: Underworld (presence of chaos, water, loose vegetation or weeds, darkness). 
The three worlds are communicated through the semantic base of the terrestrial world, Kay Pacha. The vertical division of the world also determines the distribution of beings. A mythical tale collected by Luis E. Valcárcel (1964) in his History of Ancient Peru shows in pictures (examples of image-sense) the vertical representation of the universe:

Two large snakes in charge of uniting the worlds came out from below, the ophidians' natural den, to go through the earthly world, one slithering in the shape of a great river, under the name of Yaku Mama or mother of the waters; the other one walking vertically, bearing two heads, of which the lower one picks up bugs from the surface and the upper one feeds on flying insects, barely moves and looks like a dry tree; it is the Sacha Mama or the mother of vegetation. After that, they go to the upper world, where the Yacu Mama becomes thunder or Illapa and the Sacha Mama becomes rainbow or Koychi. (Válcarcel 1964, Vol. I: 85)

The second, horizontal scheme is also ruled by the logic of the concrete and defined by two coordinates: from left to right and from front to back, creating a square shape which relates to number four, related in an isomorphic way to the four horizons. It is interesting to mention that the four paths or ways are spacetime universals, which constitute a complex chronotope, and it is necessary to know how to translate this for other cultures (Torop 2002, 2003).

The square was indeed a highly transcendent poetic symbol in the Quechua culture due to a number of configurations and contributions that allow this geometric shape to be logically associated with the trapezium (a variant of the square), with the rectangle, with the circle, and with the number four. The square modelled the world and put together the main parameters of the cosmos. As can be found in the aforementioned History of Ancient Peru (Valcárcel 1964), many objects were isomorphic in relation to the cosmos and repeated the square shape of the world scheme: spaces inhabited by men or gods ( cancha) were square in shape as were also the cut and polished stones with which they designed the walls of temples and palaces; the squares and the urban layout; the figure that contained the divine symbols in the tukapus (ancient textiles covered with geometric iconographic elements), royal fabrics and the cradles of newborn children. The square transmitted the image of an ideally stable structure, which was emphasized in the name of the Incan state Tahuantin Suyo that referred to the four universal paths or directions, the four orientations and the four ages of the world. The meaning of a set of four components spread to other spheres: number four symbolized the tribes that 
formed the confederation of the Ayar brothers; social classes were classified with the square; it was part of a swearing ritual, performed by putting four fingers on the mouth. Even a deity, the son of the God Wira Kocha, was named Tawa Kapak or Lord of the Square (Almeida 2009).

Mythopoetical spatial schemes are quite ancient and, according to Toporov (2002c, 2002d, 2002e), both the vertical and horizontal can be found in millenary cultures. In Tahuantin Suyo, the sacred character of space (Almeida 2009 ) is projected onto every work of architecture, so that it can carry a myth, for example that of primal creation: cosmos would be represented by a natural plateau and architectural constructions with neatly defined shapes, while chaos would be represented by the surrounding abyss, the emptiness, the formless space.

In summary, the Quechua mythopoetical model constructs and reflects the entire universe not only holistically, but also hologrammatically, because everything is divisible into parts and each part belongs to a whole (Morin 2002: 112-116), while guiding us to behave correctly in accordance with the cosmos, nature, life and ourselves.

\section{The logic of the concrete in the ancient thought of the Quechua culture}

In this section, we shall return to the proposal that the logic of the concrete is articulated organically within the mythopoetical dimension of the Quechua culture, which hopefully can complement the proposals already put forward. The logic of the concrete is a proposition of powerful heuristic value that was put forth in El pensamiento salvaje (The Savage Mind) by Lévi-Strauss (1964) and was expressed on an epistemological level in materialistic terms by Spirkin (1965) in his book El Origen de la Conciencia Humana (The Origin of Human Consciousness). For ancient cultures, this approach establishes a possibility and an obligation of their cognitive recognition by hegemonic cultures that have always subordinated non-writing cultures by insisting on their inferiority.

Although the logic of the concrete has been paving the way to the recognition of other forms of knowledge for many years already, as we have suggested with regard to the Quechua mythopoetical model, this idea has not been taken up as frequently as it deserves. Actually there are but a few studies that have taken up this idea and elaborated it in terms of cognitive processes; 
this can be thought of as a symptomatic absence in several fields that has to be overcome since it is directly linked with issues of cultural/intercultural translation (Lotman 1996a; Torop 2010).

According to the anthropologist Claude Lévi-Strauss, a myth responds to thinking that, although not opposed to Western rationality, is related to savage thinking, which is as logical as that of the modern West, but obeys the logic of the concrete: the difference lies in that while Western thinking operates with concepts, mythological thinking operates with image-senses, integrating a poetic dimension to the construction of mythical schemes.

The anthropologist suggests that although in mythical thinking there are no logical categories like the ones in Western thought, we cannot deny that there is a well-structured logic in myths which allows us

to show how empirical categories - such as the categories of the raw and the cooked, the fresh and the decayed, the moistened and the burned, etc., which can only be accurately defined by ethnographic observation and, in each instance, by adopting the standpoint of a particular culture - can nevertheless be used as conceptual tools to elaborate abstract ideas and combine them in the form of propositions. (Lévi-Strauss 1972: 11)

To Spirkin (1965), the first category of thinking is that of the concrete, or in other words, what is given through the contemplation of the world. Such is the beginning of the path that leads to the formation of concepts which reflect the aspects and properties of objects. Concepts have their origin in the practical activities and social relations of people. Categories of thought have their origins in specific sensitive forms: ethics in land distribution; aesthetics in the feeling that light produces; space in the agglomerate of things; time in motion.

The thinking in the early days of human consciousness (Spirkin 1965: 269) has shaped key categories, including those of time and space, quantity and quality, causality and law. We have ordered their appearance simply to analyze their essential aspects, but the categories may at any time pass dialectically from one into another. In Quechua thought, categories were closely interrelated, which gives evidence to the concrete modality of thinking.

The concreteness of space in Quechua thought is evident in the measurement of lands. In his travels through Peru, Antonio Raimondi noted that "at many inland locations where the terrain is quite uneven, the league (heiress of tupu in Quechua) is shorter and one could say no longer than 4 kilometres. It is worth noting that in Peru a league is a measure of time, rather 
than one of distance" (Rowstorowski 1981: 386). With the development of historical processes, "quantitative" standards for measuring space and time were established. The word tupu refers to a unit of measurement which no longer relates to the human body as reference as was the case in the early days of the formation of logical categories (Spirkin 1965; Almeida 2005). The concept of tupu had a relative meaning, i.e. rather than being a fixed measure, the quality of soil was taken into account and according to that, the necessary rest time was calculated so that the common people always had land for their livelihood (Rowstorowski 1981).

Concrete thought is also evident in the measurement of time. The rhythms of life, of nature and of people themselves served as criteria for cyclical measuring of time. Apparently, the first division was the day (punchay), the time of clarity, which had the night, the season of darkness, as its opposite; these categories were linked to work, rest, food and the overnight fast (Almeida 2005). Another example of the logic of the concrete survives in the Quechua language which preserves the original way of naming numbers in relation to fingers. Shuk means 'one', and when counting with the fingers of the other hand, the word shukta is used, which means 'the first finger of your other hand' or 'six'.

The density of mythopoetical thinking, which is intrinsically linked to the logic of the concrete, can be better studied with the complexity and transdisciplinarity approach, resorting to sciences like psychology, linguistics, semiotics, formal logic, mathematics and physics, among others. As we proposed in the previous section, this thinking is based on images that condense cognitive forms differently than does Cartesian thought.

In his famous letter to Jacques Hadamard on the psychology of invention, Albert Einstein states that elements of thought seem to him like pictures and more or less clear signs of physical reality, and that these images and signs are freely generated and combined by consciousness, related to thought without words, the non-verbal thinking (Peurose 1991: 525). In addition, Einstein proposes a new model of space-time, in which the two concepts should be coordinated to form a single chronotopic term, which leads us directly to the Quechua concept of Pacha, which is simultaneously space and time (Kuznetsov 1977: 233). We can therefore see that mythic images arouse a keen interest in modern science, especially the physicists, who see in them similarities with the image of the world that modern physics has proposed, 
considering such categories as theoretical fields, wave-particle duality, fuzzy relations, etc. (Rössner 1989: 6).

On the basis of everything that has so far been said about the logic of the concrete and its relationship to the Quechua mythopoetical model of the world, we will illustrate, with several cultural productions ranging from language to myth and rite, these two nodal features of this ancestral culture.

\section{Uniduality of space and time}

An emblematic example of the logic of the concrete is related to the uniduality of space and time, which are linguistically and cognitively linked: Quechua language uses the same lexemes to refer to both space and time as a unit. Indeed, as we have stated, these are lexemes linked to a different logic than that of Spanish (or English), as can be seen in the following example:

Naupa: forward and past

Kay: here and present

K'ipa: behind and future

This spatiotemporal pattern entails a problem for cultural/transcultural translation given the fact that Quechua's spatiotemporal order has an unidual character, and so differs from the Spanish (and English) at the cognitive level. In Spanish (and English), lexemes for space and time are separated from one another, and their order is opposite to the one in Quechua: the past is behind, the present is the current moment, and the future is ahead. In the Quechua language, space-time constitutes a chronotopic unit which follows a rather different cognitive process: the past is ahead, the present is right here and the future is behind. The spatiotemporal location can be explained by the logic of the concrete: the past is in front because it is something known, something already lived; the future is behind as it is something unknown since it has not been lived or experienced yet (Almeida, Haidar 1979). 


\section{The Yacana Myth}

Next, we address the myth of Yacana (the llama, a camelid of the Andes in South America). When translating it from the Quechua language into Spanish (or English), issues of cultural translation are amplified by linguistic translation, since an agglutinative language, Quechua, needs to be translated into a flexional language.

Quechua version

Imanan huk Yacana ŝutiyuq hanaq pachamanta uraykumun yakukta upyaypaq.

Kay Yacana ñiŝqanchkŝi llamap kamaqin cielo ñiqta ĉawpikta purimun. Nuqanchik runakunapaŝ rikunchikmi ari yanalla hamuqta. Chaymanta chay Yacana ñiŝqanchikŝi mayu ukukta purimun. Ancha hatunmi ari. Yanayaŝpa cielo ñiqta iŝkay ñawiyuq kukanpaŝ ancha hatun kaptin hamun. Kaytam runakuna Yacana ñinku.

Kay Yacana niŝqanchikŝi $\tilde{n} a$ huk runap kuŝimpi venturan kaptin paysawa urmamuŝspa mayqin pukyullamantapaŝ yakuta upyaq. Chaysi chay runa ancha millwasapa ñitimuptin chay millwanta wakinnin runaqa tiraq. Kay rikuchikuysî tuta kaq. Hinaŝpaŝ qayantin pacha paqarimuptinqa chay millwa tiraŝqanta rikuq.

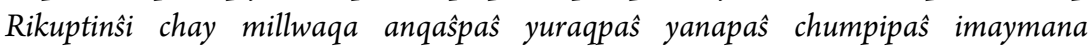
rikchaqkuna millwaŝ taku taku kaq. Kaytaŝ kanan mana llamayuq kaŝpapaŝ tuylla rantikuŝpa pachan rikuŝ̀qanpi tiraŝqanpi muchaq karqan. $\tilde{N} a$ muchaŝpaŝ huk cìna llamakta urquntawan rantikuq. Chay rantiŝqallanmantaŝ ñaĉqa ishay kimsa waranqa llamamanpaŝ ćayaq. Kay ñiŝqanchiktaqa ancha achka runaktaŝ ñawpa pacha kay tukuy provinciapi hina rikuchikurqan.

Kay Yacana ñiŝanchiktaqŝsi ĉawpituta mana pipaŝ yaĉaptin mamaquĉamanta tukuy yakukta upyan. Mana upyaptinqa utqallaŝ tukuy hinantin mundokta pampawachwan. Kay Yacana ñiŝanchikpi aŝlla yanalla ñawpaqnin chaytam "yutum" ñintu. Chaymantari kay Yacanataqŝi wawayuq. Wawanpaŝ ñuñukuptinŝi riscan.?

English version (translated from Spanish by Ileana Almeida)

We will tell how a black spot came down from heaven to drink water.

Yacana, they say, is the black shadow that governs the llamas. She walks through the centre of heaven, and we men see her becoming all dark. When she arrives, she walks under the rivers. She is really great. She comes across the sky getting increasingly black. She comes blackening the sky. She has two eyes and a long neck. This shadow men call Yacana.

7 Gerald Taylor (2001) transcribes this text according to the "normalized" Quechua writing of Peru. 
They say that Yacana came down to drink water from a spring and fell on a happy man. In this way the man was covered with her wool. Other men could shear it. This happened during the night. At the dawn of the next day, the man looked at the wool. It was blue, white, black, dark yellow. It had all the colours together. As he had no llamas, he sold the wool. He bowed to the Yacana in the same spot where he fell. After the rite of worship he bought a male llama and a female llama. With this pair, he managed to get two or three thousand llamas. In olden times, this happened to many people of this province. They say this Yacana descends at midnight. When no one is looking, she takes all the water from the sea. If she did not drink it, the whole world would be covered.

The myth builds upon images from the collective memory of the ancient Quechua culture. The llama is the animal of ritual offering, sacrificed at great festivals dedicated to the Sun; its blood, wool and fat carry the meaning of sacred ritual. Yacana is the proper and sacred name of the llama. ${ }^{8}$

At the same time, Yacana is also an extinguished star with no light, whose sacred meaning is found in the continuum that it establishes between three cosmic dimensions: the upper world, the terrestrial world and the underworld. It is a continuum that balances the existence of these three dimensions. The llama is a mythological figure-subject of heaven, earth and the underworld. In other words, the llama is part of the upper world, which goes down to the earthly world to interact with humans, and descends into the underworld to drink water from underground rivers. The ability to establish a continuum between the three dimensions of the cosmos, designed in a vertical pattern (reminiscent of the symbol of the world tree), creates a link with the Mesoamerican symbol of Quetzalcoatl, the serpent-bird or the feathered serpent that connects the underworld, the terrestrial world, and the upper world.

In addition, the llama clearly plays the role of a cultural hero who prevents a catastrophe that could annihilate mankind. Evidence of this role is found in a text which the chronicler Bernabé Cobo (Valcárcel 1964, Vol. II: 386) picked up at the Puna of Andamarca, near Cusco: "It is said that two months before the Flood, the shepherds noted that the llamas were possessed by great sorrow."

8 The myth is included in a manuscript from the end of the 16th century, which José María Arguedas published under the title Dioses y Hombres Warochirí. It introduces us to the realm of Quechua mythopoiesis at the time of Tahuantin Suyo, when the Incan Empire still dominated the Andean Cordillera cultures. 
According to the primary themes of mythology, the poetic image of the llama also signifies the victory of cosmos, ordered and organized into three levels above the primitive chaos symbolized by the sea, which is always unpredictable and related with the aquatic abyss through mythical thinking. Finally, the image-llama, which gives evidence of its belonging to the astral world, comes down to Earth in a miraculous manner, bringing with it (in terms of cosmogony) Kuichi colours or the rainbow, which is also recounted in the myth of the two snakes mentioned earlier.

These two symbols, the Llama in Peru and Quetzalcoatl in México, have the function of overcoming the chaos, giving coherence to the cosmos on the basis of a particular thought, the logic of the concrete and the mythopoetical model, bringing together on the vertical axis the three spatiotemporal levels already analysed.

\section{Pacha, Pachamama and Mama in the Quechua semiosphere and semantic fields from the viewpoint of the logic of the concrete}

In the Quechua cosmogony, pacha is the universe, the cosmos with a sense of wholeness, meaning infinite space-time; therefore it is a unidual concept, inseparable and complex. As mentioned above, it is also space-time related to the vertical axis of the three dimensions and to the horizontal axis which covers the four directions of the world. Pacha is a nucleus with different meanings that can encompass several semantic fields; it appears as a lexeme in syntagmas and proper names attributed to the Inca rulers who were the only ones who could have a proper name linked to this sacred core, as we will exemplify further ahead.

Among the complex meanings this concept may have, we refer to a very unique one: pacha also means the spider, a symbol-image of the cosmic weave, the primal substance of the universe. According to the logic of the concrete, it was thought that there was a cosmic fabric made by a spider that was weaving herself simultaneously (Toporov 2002a: 38); a cosmic spider weaving a cosmic web arranging the fabrics as a symbolic material of the creation of the world. Consequently, it can also mean woven clothing, the art of weaving or awani: the most expressive form of Quechua aesthetics. 
Additionally, spiders were also used to foretell the future, based on their foundational relationship with the universe. They were handled by soothsayers who were called pachakuk or pacharikuc, magicians who could guess at destiny through spiders of a species known as Pacha by performing the following ritual: the spider was to walk on a blanket; if she lost one leg or more it was a bad omen; if the spider kept her legs it was a good omen (Valcárcel 1964, Vol. II: 67).

The concept of pacha appears in various agglutinating words to name the gods, the Inca rulers, and ritual objects:

Pachakamak - The god who commands, who makes the laws.

Pachakutek - The god who refounds, re-establishes the world again. In many cultures there is a god of this kind who recasts the world and its beings.

Wira Kocha Pachayachachik - the Andean creator god of chaos and cosmos, "The one who reveals the world".

Pachamanka - Pot of earth: there are heated stones in a hole in the earth; here one can cook meat, tubers, etc. It has a ceremonial origin, and its original ritual function is present in the memory of Quechua culture. There are several peoples that maintain this culinary technique with variations, but with the same sacral principle.

The concept of Pachamama has a relationship with this nodal concept in the Quechua mythopoiesis, and includes two major categories: pacha, with all the meanings we have mentioned, and mama that does not correspond to the meaning it has in Spanish ('mother'), which introduces problems of linguistic and cultural translation. The whole syntagm presents issues of these two types of translation not only because it belongs to various semantic fields but because the translation of Mother Earth (Pachamama) does not have the same meaning these lexemes have in Spanish. In Quechua, Pachamama is eternal, a symbol of infinity; it has neither beginning nor end; it also represents the universal principle of fertility, it is sacred and has the status of a living being - features that are not present in the syntagm 'Mother Earth' in Spanish.

All that has been said so far implies the obligation of rigorous further research on the semantic fields of both semiospheres, in order to go beyond linguistic translations and to achieve a reconstruction of the meaning departing from the right cultural categories (Torop 2002, 2003, 2010) based on the logic of the concrete, which is a theoretical and methodological requirement that has hardly been taken into account. 
The concept of mama has no equivalent in Spanish, because its meaning is linked to the worldview of the Quechua semiosphere: mama, besides being the beginning of fertilization, the origin of life, also means the protective spirit of everything that is alive. Mama is also used as an augmentative in current spoken Quechua (Quichua) as illustrated by the following examples:

\author{
Pachamama - Mother of the Universe, Mother Earth \\ were considered 'saramama' \\ Kokamama - Mother of coca, the protector of coca \\ Yakumama - Mother of water, the protector of water \\ Akomama - Mother of potatoes, the protector of potatoes \\ Cochamama - Boundless sea
}

Saramama - Mother of corn, protector of corn. Large or unusually shaped cobs

\title{
World tree and its symbol-images
}

The world tree, a symbol of the vertical axis of the world, is a characteristic image of the mythological consciousness that embodies a universal conception of the world; it is found in many cultures, in its pure form or in some variants. The image of the world tree plays a special organizing role for concrete mythological systems, defining their internal structure and their fundamental parameters. This symbol helps to articulate the zones and fundamental spatial levels of the universe mentioned above; temporal stages (past-present-future, day-night, propitious and unpropitious times of the year); genealogical aspects (ancestors-current generation-descendants); the etiological sphere (cause and effect, the favourable, neutral and unfavourable); anatomy (three body parts: head, torso and legs), and finally, three types of elements (fire, earth and water) (Toporov 2002b: 47). In classical Quechua culture, during the Tahuantin Suyo era, the world tree was represented by different symbolimages: the Inti watana (a stone pillar that marks the passing of the sun, the most important spot at Machu Picchu, and means "the world axis"); the Kenko sculpture in the upper part of Cusco, in the Sacred Valley of the Incas; the symbol chacana (a square with saw-toothed sides and a hole in the middle), which appears in many architectural works and also refers to the continuum of semantic binary oppositions, describing the basic parameters of the universe (Gasparini, Margolies 1977). 


\section{The Pujilí dancer - world-man: symbol-images}

Nowadays, even though it has lost its original meaning, at ritual festivals of the indigenous people from the Pujilí area of the Cotopaxi province, the Pujilí dancer figure represents the world-man, as we have mentioned, and constitutes its central symbol-image, since it condenses many aspects of what has been stated about the mythopoetical model and the logic of the concrete. In this sense, it can be thought of as one of the versions of the world tree, according to the statements of the semioticians of the Tartu School.

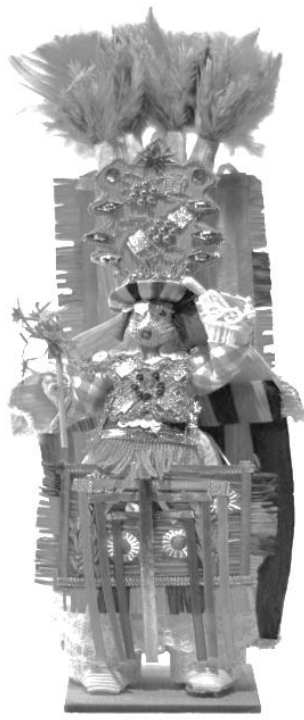

Figure 2. Pujilí dancer, front.

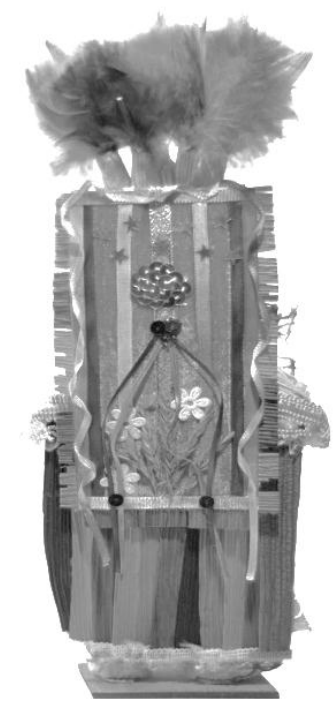

Figure 3. Pujilí dancer, back.

On his head the dancer wears a high trapezoidal tuft which signifies the height, the sky, where most of the ornaments and shine are concentrated. It is so high that it is inaccessible. The tuft means power, being in command. The dancer wears white clothes underneath to signify that he is a "spirit"; his face is covered by a mask that turns him into a special being, into another person, sacralizing him.

On the dancer's chest, embroideries remain that remind of the relations of the square and the circle. There is a cross on his chest marking the four directions of the world, which are homologous to the four directions or paths 
of the universe; the cross is also embroidered with human, animal, flower and heart figures.

Another garment hangs from the waist to the knees. It is also ornamented but not as meticulously as the top pieces. Apparently it represents the underworld and is decorated with colourful ribbons, zigzag lines, possibly following the thought that snakes, who represent the underworld space, are aquatic beings.

Every year these indigenous dancers go to the (square-shaped) city squares to celebrate their holidays; they make a stop at each corner and mark the area with particularly vigorous steps: this is when the memory of the Quechua culture emerges visually. It is always a sacred personage that dances with great solemnity at the annual Corpus Christi celebration.

\section{Rhetoric and aesthetics from the viewpoint of the logic of the concrete}

To complete our proposals regarding the logic of the concrete and the Quechua mythopoetical model, it is fundamental to consider the aestheticrhetorical dimension in mythological cultural productions. We start from Golosovker's views on the poetics of myth. Golosovker (Zenkin 1988: 299) asserts that mythological consciousness corresponds to an imaginative absolute; imagination in the mythological consciousness, claims the author, "is a particular form of knowledge". In non-Cartesian thinking, i.e., within the logic of the "miraculous", conceptions of the natural and social surroundings are independent of concepts and formal logical categories. As Golosovker (Zenkin 1988: 299-231) affirms, myth aesthetic has its particularity, its ontological character in which the image is not representation, but meaning, because in the myth a concrete object becomes a symbol.

Based on these proposals, we can understand the ontological aesthetics as linked to the concrete, which allows Lotman and Uspenski to assert that there is no metaphor in myth (Lotman, Uspenski 2000a: 156). The above-said can be clearly understood if we place ourselves in the logic of the concrete. What belongs to the aesthetic-rhetorical realm for Western thinking, is thought or understood as ontological properties, not Aristotelian figures, in ancient cultures. The poetic language of myth obeys these ontological workings that cannot be explained unless we adopt Golosovker's and Lotman's positions as our point of departure. 
In these terms, we need to address the peculiar status of the rhetoricalaesthetic dimension linked to the sacred in ancestral cultures, and for this end, the complexity and transdisciplinarity approach becomes a very helpful tool. The re-founding of these dimensions is necessary in order to give an account of their different functions in diverse cultures, mainly those guided by the logic of the concrete.

On the other hand, considering the relationship between rhetoric and cognition, in which cognitive processes are extended to other parameters, we can observe that in ancestral cultures and languages the metaphor and the symbol exceed the purely aesthetic realm and appear continuously in everyday language. Thus, Jakobson's poetic function (1975) is extended to influence many productions, not only mythical, but also sacred songs as well as formulas used in various rituals. From another angle, we take up the ideas proposed by Lakoff and Johnson (1986) concerning the cognitive function of metaphor and its presence in several kinds of language.

In American, African, Australian and non-Western languages, figures of thought are universal as such, but analogies, comparisons, contradictions may have other materializations based on the logic of the concrete. In ancestral languages such as Quechua, Nahuatl, Zapoteco or African and Australian languages, space becomes metaphorized, which allows us to think that there is a continuum between metaphor and symbol. For example, we can take the myths of the two snakes and the llama in which the tropes appear linked to the mythopoetical model and to the concrete, in order to visualize the three dimensions on the vertical axis. In other versions of this model, we can find mountains, sacred trees, caves as symbols, as well as lexemes referring to body parts projected onto dwellings besides other operations that we have analysed.

\section{Conclusions}

In this article, we have taken the Quechua culture as our primary object of study in order to awaken and enhance a renewed interest in it. We have also shown how the history of Quechua culture, much like its typology, can be described in the form of a deep theoretical interpretation with innovative concepts and categories that enable dialogues and cultural translations within a global consciousness that opens up spaces for necessary cross-cultural contacts. Every culture is in itself the result of long translation processes, which means that all cultures, beyond their differences, find points of contact with others. 
Like every culture, Quechua is the result of extensive processes of translation, through which it maintains the ability to adopt and adapt external or alien features (even those imposed at different stages of its history) to its own semiosphere, which opens perspectives for the future.

Every culture is a source of creativity and as such it is universal. Every culture reflects in its own time and way basic human life experience and contains universal elements, as we have seen. In this regard, the study of Quechua culture constitutes a humanistic priority due to the memory of culture that has persisted in it, in a movement from the past to the present, up to the future.

From a transdisciplinary perspective, we have explained mythopoiesis as a peculiar form of knowledge which combines cognitive and poetic creative processes, linked to the logic of the concrete. Mythopoiesis regards myths as involving cyclical, repetitive, and dynamic movements represented by spirals, symbols of infinite space-time. Therefore, joining episteme to epistemology, as Edgar Morin suggests in various texts, we may be able to reconstruct the complexity of human cognitive processes, which cannot be fully explained by Western Aristotelian or Cartesian logic alone.

The issues of cultural translation raised by Juri Lotman and Peeter Torop pose challenges for intercultural and transcultural relationships that every culture has to face throughout its entire historical development. Due to globalization, cultural translation implies transcultural translation processes that keep getting more conflictive and tensive. In this article, which is part of a larger research work on the semiotics of the Quechua culture, we have only outlined some difficulties that may arise in cultural translations between Quechua and Spanish; we have not attempted to propose solutions, but rather to problematize aspects involved in any cultural/transcultural translation.

Finally, we present how the Ecuadorian indigenous movement represents Pachamama visually: 


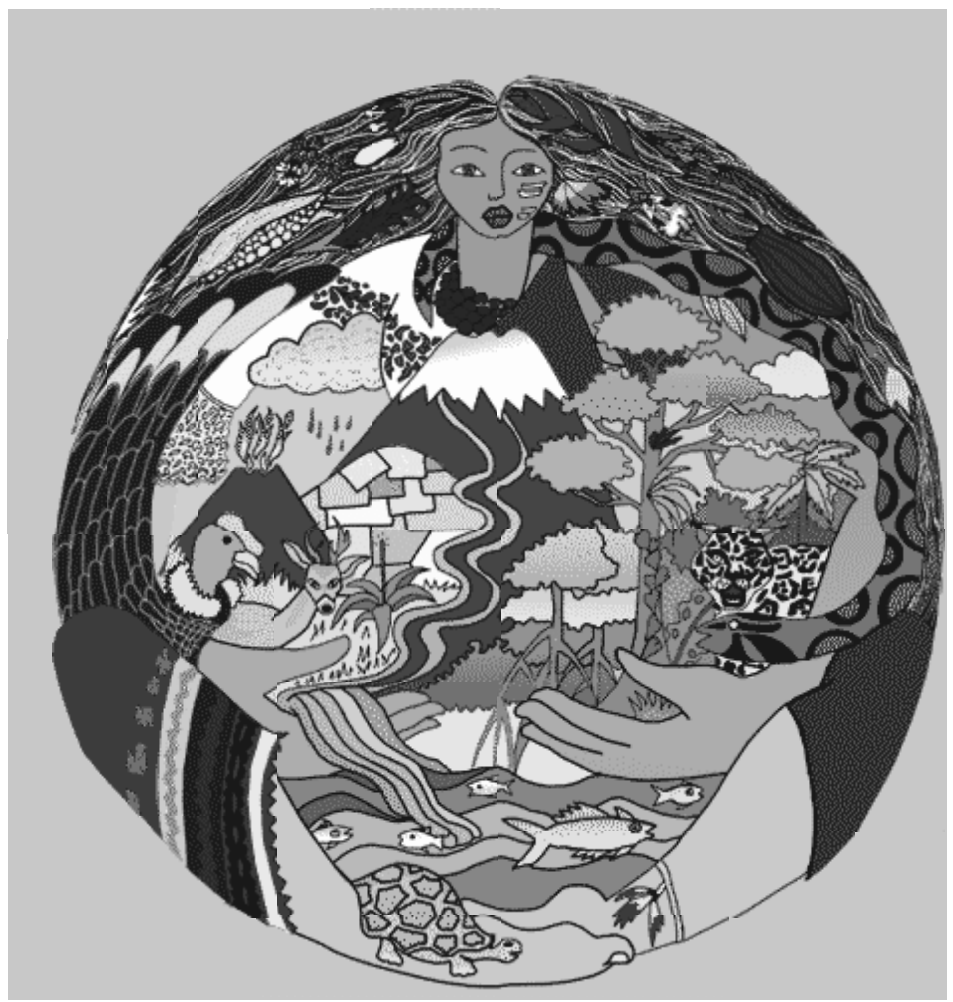

Figure 4. Pachamama (www.conaie.org)

In this image (Fig. 4), Pachamama is presented as Mother Earth that incorporates the principle of fertility of everything living, emphasizing the continuum between nature, animals, plants, rivers, hills, humans, the four universal elements: water, earth, fire and air. Figurative construction produces multiple meanings in order to give account of this ancient symbol, present in the memory of culture. The symbolic construction of Pachamama undoubtedly projects meanings other than what our planet Earth means to Western cultures and this constitutes a problem for cultural/transcultural translation, which can, however, be solved by following the guidelines that take into consideration the logic of the concrete of ancestral thought. 


\section{References}

Aguilar Páez, Rafael 1970[1586]. Gramática Quechua y vocabularios (anónimo). Adaptación de la primera edición de la obra de Antonio Ricardo "Arte y vocabvlario en la lengva general del perv llamada quichua, y en la lengua española". Lima: Universidad Nacional Mayor de San Marcos.

Almeida, Ileana 2005. Historia del pueblo Kechua. Quito: Editorial Abya Yala.

- 2009. El modelo mito-poético del mundo en la cultura quechua durante la época del Tawantin Suyo. In: Arcos Cabrera, Carlos (ed.), Sociedad, cultura y literatura. 50 años FLACSO. Quito: RisperGraf C. A., 271-283.

Almeida, Ileana; Haidar, Julieta 1979. Hacia un estudio semántico del quichua ecuatoriano. In: Almeida, Ileana et al. Lengua y Cultura en el Ecuador. Otavalo: Instituto Otavaleño de Antropología, 327-342.

- forthcoming. El significado del mito de los Cuatro Hermanos Ayar. Estudio semiótico. (En preparación.)

Choy, Emilio 1978[1962]. Desarrollo del pensamiento especulativo en la Sociedad Esclavista de los Incas. In: Soriano, Waldemar Espinoza (ed.), Los Modos de Producción en el Imperio de los Incas. Lima: Mantaro-Grafital, 95-112.

Doig, Federico Kauffmann 1973. Manual de Arqueología Peruana. Lima: Ediciones Peisa.

Foucault, Michel 1972. La Arqueología del Saber. México: Siglo XXI Editores.

Gasparini, Graziano; Margolies, Luisa 1977. Arquitectura Inka. Caracas: Centro de Investigaciones Históricas y estéticas, Facultad de Arquitectura y Urbanismo.

Godelier, Maurice 1978[1974]. El concepto de formación económica y social: El Ejemplo de los Incas. In: Soriano, Waldemar Espinoza (ed.), Los Modos de Producción en el Imperio de los Incas. Lima: Mantaro-Grafital, 265-283.

Haidar, Julieta 2004. La epistemología compleja y la transdisciplinariedad en las Ciencias Sociales y las Ciencias del Lenguaje. Ponencia inédita presentada en la Universidad de Culiacán, México.

Jakobson, Roman 1975. Ensayos de Lingüística General. Barcelona: Seix Barral.

Kuznetsov, Boris 1977. Dante, Galileo, Einstein. Revista Ciencias Sociales 2: 229-237.

Lakoff, George; Johnson, Mark 1986. Metáforas de la vida cotidiana. Madrid: Cátedra.

Lévi-Strauss, Claude 1964. El pensamiento salvaje. Buenos Aires: Fondo de Cultura Económica.

- 1972. Mitológicas I. Lo Crudo y lo Cocido. Buenos Aires: Fondo de Cultura Económica.

- 2002. Mito y Significado. Madrid: Alianza Editorial.

Lotman, Iuri 1996a[1984]. Acerca de la semiosfera. In: Lotman, Iuri M. La Semiosfera I. Semiótica de la cultura y del texto. (Navarro, Desiderio, ed.) Madrid: Ediciones Cátedra, 21-42.

- 1996b[1983]. Asimetría y diálogo. In: Lotman, Iuri M. La Semiosfera I. Semiótica de la cultura y del texto. (Navarro, Desiderio, ed.) Madrid: Ediciones Cátedra, 43-60.

- 1996c[1981]. El texto en el texto. In: Lotman, Iuri M. La Semiosfera I. Semiótica de la cultura y del texto. (Navarro, Desiderio, ed.) Madrid: Ediciones Cátedra, 91-109. 
- 1996d[1992]. El texto y el poliglotismo de la cultura. In: Lotman, Iuri M. La Semiosfera I. Semiótica de la cultura y del texto. (Navarro, Desiderio, ed.) Madrid: Ediciones Cátedra, 83-90.

- 1996e[1985]. La memoria a la luz de la culturologia. In: Lotman, Iuri M. La Semiosfera I. Semiótica de la cultura y del texto. (Navarro, Desiderio, ed.) Madrid: Ediciones Cátedra, 157-161.

- 1998a[1987]. Algunas ideas sobre la tipología de las culturas. In: Lotman, Iuri M. La Semiosfera II. Semiótica de la cultura, del texto, de la conducta y del espacio. (Navarro, Desiderio, ed.) Madrid: Ediciones Cátedra, 81-92.

- 1998b[1978]. El fenómeno de la cultura. In: Lotman, Iuri M. La Semiosfera II. Semiótica de la cultura, del texto, de la conducta y del espacio. (Navarro, Desiderio, ed.) Madrid: Ediciones Cátedra, 25-41.

Lotman, Iuri; Mints, Zara G. 1996[1981]. Literatura y mitología. In: Lotman, Iuri M. La Semiosfera I. Semiótica de la cultura y del texto. (Navarro, Desiderio, ed.) Madrid: Ediciones Cátedra, 190-213.

Lotman, Iuri; Uspenski, Boris 2000a[1973]. Mito, nombre y cultura. In: Lotman, Iuri M. La Semiosfera III. Semiótica de las artes et de la cultura. (Navarro, Desiderio, ed.) Madrid: Ediciones Cátedra, 143-167.

- 2000b[1979]. Sobre el mecanismo semiótico de la cultura. In: Lotman, Iuri M. La Semiosfera III. Semiótica de las artes et de la cultura. (Navarro, Desiderio, ed.) Madrid: Ediciones Cátedra, 168-193.

Morin, Edgar 1997. Introducción al pensamiento complejo. Barcelona: Gedisa.

- 2002. El conocimiento del conocimiento. Madrid: Editorial Cátedra.

Nicolescu, Basarab 2009[1996]. La Transdisciplinariedad. Manifiesto. Xalapa: Universidad Veracuzana, México.

Nuñez, Carlos 1978[1954]. Teoría del desarrollo incásico. In: Soriano, Waldemar Espinoza (ed.), Los Modos de Producción en el Imperio de los Incas. Lima: MantaroGrafital, 15-87.

Peurose, Roger 1991. La nueva mente del emperador. Madrid: Mondadori.

Rössner, Michael 1989. Concepto y esencia del mito. Revista Humboldt 97: 4-7.

Rostworowski de Diez Canseco, María 1981. Mediciones y Cómputos en el Antiguo Perú. In: Lechtman, Heather; Soldi, Ana María (eds.), Runakunap Kawsayninkupaq Rurasqankunaqa: La tecnología en el mundo andino. Vol. 1. México: Universidad Nacional Autónoma de México, 379-405.

Spirkin A., 1965. El Origen de la Conciencia Humana. Buenos Aires: Editoriales Platina / Stilograf.

Taylor, Gerald 2001. Huarochirí: manuscrito quechua del siglo XVII. Lima: Lluvia Editores.

Toporov, Vladimir 2002a. Araña. In: Acosta, Rinaldo (ed.), Árbol del Mundo. Diccionario de imágenes, símbolos y términos mitológicos. La Habana: Colección Criterios, Casa de las Américas / UNEAC: 38-39.

- 2002b. Árbol del mundo. In: Acosta, Rinaldo (ed.), Árbol del Mundo. Diccionario de imágenes, símbolos y términos mitológicos. La Habana: Colección Criterios, Casa de las Américas / UNEAC: 45-54. 
- 2002c. Cosmos. In: Acosta, Rinaldo (ed.), Árbol del Mundo. Diccionario de imágenes, símbolos y términos mitológicos. La Habana: Colección Criterios, Casa de las Américas / UNEAC: $134-136$.

- 2002d. Cuadrado. In: Acosta, Rinaldo (ed.), Árbol del Mundo. Diccionario de imágenes, símbolos y términos mitológicos. La Habana: Colección Criterios, Casa de las Américas / UNEAC: 141-143.

- 2002e. Espacio. In: Acosta, Rinaldo (ed.), Árbol del Mundo. Diccionario de imágenes, símbolos y términos mitológicos. La Habana: Colección Criterios, Casa de las Américas / UNEAC: $178-182$.

- 2002f. Modelo (mitopoético) del mundo. In: Acosta, Rinaldo (ed.), Árbol del Mundo. Diccionario de imágenes, símbolos y términos mitológicos. La Habana: Colección Criterios, Casa de las Américas / UNEAC: 330-336.

Torop, Peeter 2002. Intersemiosis y traducción intersemiótica. Cuicuilco. Revista de la Escuela Nacional de Antropologia e Historia (ENAH). Análisis del discurso y semiótica de la cultura: perspectivas analíticas para el tercer milenio, Tomo II, mayo-agosto, 9(25): $13-42$.

- 2003. Semiótica de la traducción, traducción de la semiótica. Entretextos. Revista Electrónica Semestral de Estudios Semióticos de la Cultura 1: 1-7.

- 2010. La traduzione totale. Tipi di proceso traduttivo nella cultura. Milano: Ulrico Hoepli.

Torres Fernández de Córdova, Glauco 1982. Diccionario kichua-castellano / yurakshimirunashimi. Cuenca, Ecuador: Casa de la Cultura Ecuatoriana.

Valcárcel, Luis E. 1964. Historia del Perú Antiguo. Volumen I, II, III. Lima: Editorial Juan Mejía Baca.

Zenkin, Sergei 1988. The logic of myth. (Review of the book by Yakov Golosovker.) Social Sciences Magazine 4, 299-301.

\section{Мифопоэтическая модель и логика конкретного в культуре кечуа. Проблемы культурного и межкультурного перевода}

В статье рассматриваются (меж)культурные проблемы перевода между испанской культурой и культурой кечуа, которые анализируются исходя из идей Юрия Аотмана и Пеэтера Торопа. В процессе перевода нужно учитывать как внешние так и внутренние границы семиосферы кечуа, оформившейся в кругу кумьтур эпохи Империи Инков (Тавантинсуйу) и испытавшей влияние конкисты. Проблем, связанных с культурой кечуа, много и они многплановы. Во-первых, язык кечуа агглютинирующий, что создает проблемы при переводе на фмективный испанский язык. Вторая и более сложная проблема - мифопоэтическая модель, исконно присущая культуре кечуа, которая пользуется не понятиями рациональной могикой, а характерными Амя мифологического мышиения поэтическими образами, преАставляя иной когнитивный паттерн. В-третьих, могика конкретного, которую выражает мифопоэтическая модель кумьтуры кечуа, затрудняет перевоА с присущей Западу абстрактной формальной могики. ОбсужАение этих тем созАает новые возможности дмя анализа. 


\section{Mütopoeetiline mudel ja konkreetsuse loogika quechua kultuuris. Kultuurilise ja transkultuurilise tõlke probleeme}

Artikkel tegeleb peamiselt quechua ja hispaania kultuuri vahelise tõlke kultuuriliste/ transkultuuriliste probleemidega, analüüsides neid lähtuvalt mõningatest Juri Lotmani ja Peeter Toropi ideedest. Tõlkeprotsessi puhul tuleb arvesse võtta nii quechua semiosfäri sisemisi kui ka välimisi piire, mis on seotud Tahuantin Suyo ajal eksisteerinud kultuuridega ning samuti kõigi muutustega, mis on tulenenud Ladina-Ameerika vallutamisest hispaanlaste poolt. Quechua kultuuri puhul on probleeme palju ja need on mitmeplaanilised. Esiteks on quechua keel aglutineeriv keel, mis tekitab probleeme tõlkimisel flekteerivasse hispaania keelde. Teiseks ja keerulisemaks probleemiks on sellesse kultuuri olemuslikult kuuluv maailma mütopoeetiline mudel, mis ei kasuta ratsionaalse loogika mõisteid, vaid müütilisele mõtlemisele omaseid poeetilisi kujundeid, esindades teistsugust kognitiivset mustrit. Kolmandaks, quechua kultuuri konkreetsuse loogika, mida väljendab mütopoeetiline mudel, teeb tõlkimise lääne abstraktsest formaalloogikast raskemaks. Arutelu nende teemade üle loob uusi analüüsivõimalusi. 